\title{
Demons and Diversity in León
}

\author{
Pamela A. Patton
}

\begin{abstract}
This article examines a wall painting of the temptation of Saint Martin in the so-called Panteón de los Reyes of San Isidoro in León, focusing on its unorthodox portrayal of Satan as an Ethiopianized, dark-skinned figure wearing a robe reflective of Fatimid textile traditions. Tracing the scene's divergent sources within the complex network of images, texts, and ideas then circulating in León, it argues that the unusually configured image constituted an innovative, intervisual response to the concerns of a palatine viewership that in the first decades of the twelfth century remained preoccupied with its own dynastic and political position, both within the Leonese kingdom and with reference to its wider European sphere.
\end{abstract}

\section{Keywords}

San Isidoro - León - Panteón de los Reyes - Satan - blackness - skin color - Saint Martin - țirāz

Objects are at their most eloquent when studied intimately, and those in the San Isidoro treasury are no exception. Many essays in this volume demonstrate how the caskets, vessels, textiles, and other precious works at the center of the Treasury project reward close scholarly scrutiny with vivid, often surprising testimony about their origins, their movements, and above all, the messages that they carried among patrons, makers, and viewers in the Leonese capital. The objects may not always be so forthcoming, however, about the nature and outlook of those who viewed them, nor about the wider web of ideas, values and aspirations within which the treasury took shape. The present article aims to remedy this by considering how an exceptional painted portrayal of the Temptation of Saint Martin, still in situ in the so-called "Panteón de los Reyes" of San Isidoro, sheds new light on the cultural sophistication and international ambitions that led the patrons of San Isidoro to bestow upon their church the costly, transculturally resonant objects that survive in the treasury today. 
The work in question is a small but lively scene located on a soffit within the extensive ensemble of vault paintings that were added to the Panteón in the early twelfth century, very likely, as Therese Martin has argued, after 1109, when

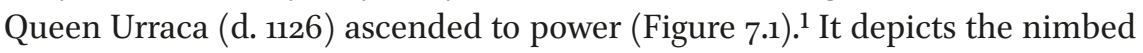
saint Martin, seated and with book in hand, confronted by a richly garbed figure whose profile face displays brown skin, a large whitened eye, and a rounded, low-bridged nose. The figure's small size and wavy hair give it a childlike, even androgynous appearance; the collar and borders of its long white robe are ornately patterned; its feet are bare. With its right hand, the figure points downward while the left, today damaged but still visible in situ, points toward Martin. The bold inscription, $\mathrm{S}[\mathrm{AN}] \mathrm{C}[\mathrm{TU}] \mathrm{S}$ MARTINUS DIXI[T] VADE SATANAS (Saint Martin said "Go [away], Satan"), reveals that this is the devil, who, according to Martin's late fourth-century biographer Sulpicius Severus, once interrupted the saint at prayers, presenting himself in royal dress and claiming to be Christ. ${ }^{2}$

The scene constitutes just a minor element of an elaborate painted program that centers on the life of Christ, set out in eight Infancy and three Passion scenes, and two imposing vault compositions of Christ in Majesty and the Vision of Saint John. Subsidiary imagery on the soffits includes the Labors

1 This article was first presented under the auspices of the interdisciplinary conference "The Medieval Iberian Treasury in the Context of Muslim-Christian Interchange" as part of the research grant The Medieval Treasury across Frontiers and Generations: The Kingdom of LeónCastilla in the Context of Muslim-Christian Interchange, c. 1050-1200 (PI Therese Martin), supported by a National Excellence in Research Grant, Spanish Ministry of Economy and Competitivity (HAR2015-68614-P) and the Princeton Institute for International and Regional Studies at Princeton University. I thank Therese Martin for inviting me to be a part of this stimulating project.

Therese Martin, Queen as King: Politics and Architectural Propaganda in Twelfth-Century Spain (Leiden: Brill, 2006), 132-152. Joan Sureda in La pintura románica en España (Aragón, Navarra, Castilla-León y Galicia) (Barcelona: Alianza Forma, 1985), 329, likewise attributed the frescoes to the period of Queen Urraca's reign, although a number of other scholars have dated them earlier, assuming their patron to have been Alfonso vi. The latter group includes Antonio Viñayo González, San Isidoro de León: Panteón de los Reyes. Albores románicos: arquitectura, escultura, pintura (León: Edilesa, 1995), 34; and Rose Walker, "The Wall Paintings in the Panteón de los Reyes at León: A Cycle of Intercession," The Art Bulletin 82/ 2 (2000): 200-225, at 209-210. For a concise overview of the scholarship, see Miguel Cortés Arrese, "Pinceladas bizantinas: pintura románica en el Panteón Real," in Real Colegiata de San Isidoro: Relicario de la monarquía leonesa, ed. Constantino Robles García and Fernando Llamazares Rodríguez (León: Edilesa, 2007), 146-167; esp. 147.

2 For the Latin, see Sulpicius Severus, Vie de Saint Martin, ed. J. Fontaine (Paris, 1967), 1:307-308 (24:4-8); a recent English translation appears in Sulpicius Severus: The Complete Works, intro., trans., and notes by Richard J. Goodrich (New York: The Newman Press, 2016), 50-51. 


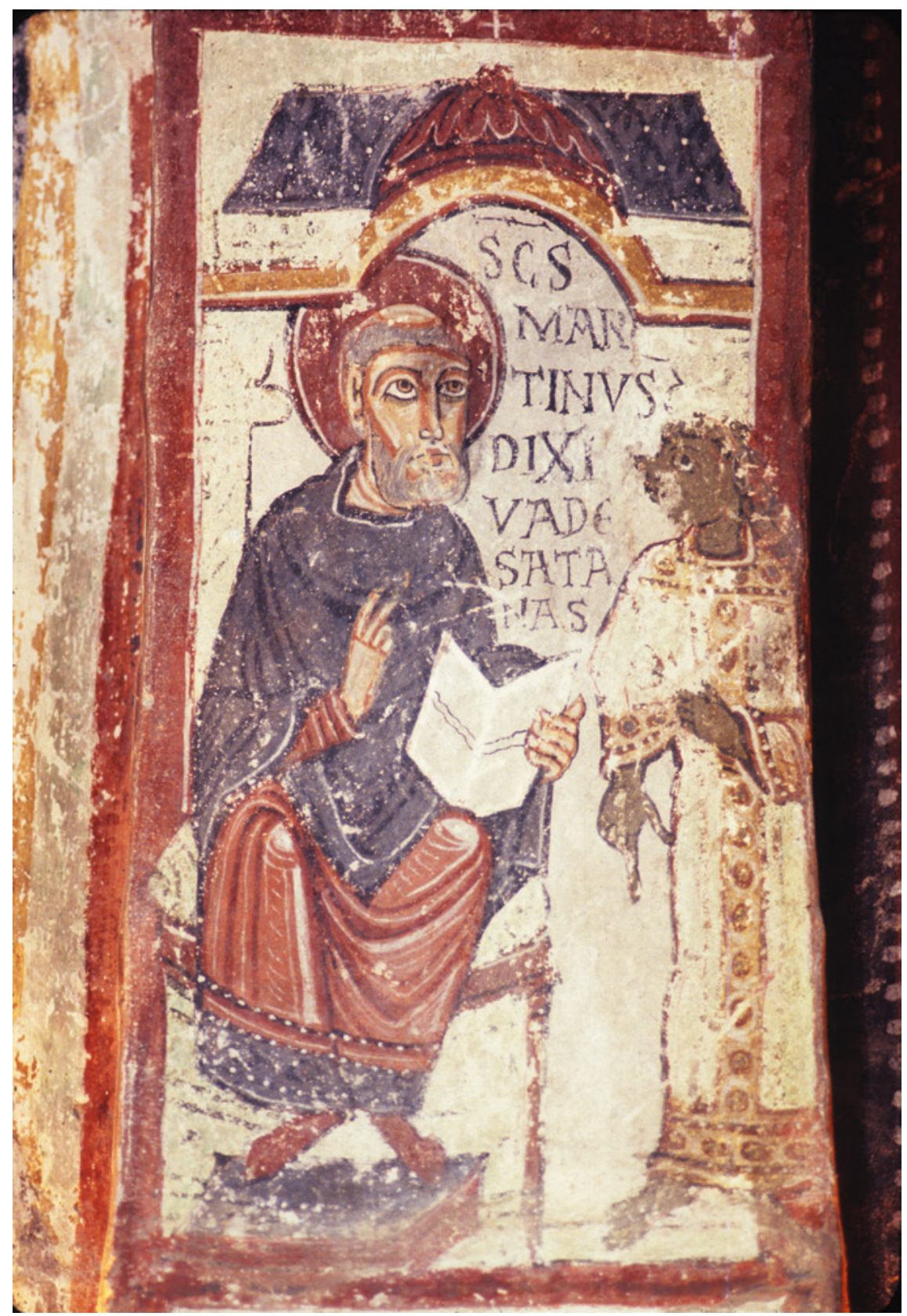

FIGURE 7.1 Temptation of St. Martin, Panteón de los Reyes, San Isidoro, León. PHOTO: JAMES D'EMILIO 
of the Months, the Zodiac, the archangels Raphael and Gabriel, the prophets Enoch and Elijah, and three other saints-Gregory, George, and Eloy—along with Martin. The presence of the French St. Martin here, although hardly the most puzzling aspect of the Panteón's painted decoration, is often ascribed to his reputation as an adversary of the devil, which may explain the unusual decision to depict his temptation at prayer rather than the far more popular episode of the saint sharing his cloak with a poor man. ${ }^{3}$

More exceptional than the subject of the scene at León is its manner of presentation. Although most scholars have identified Sulpicius Severus's Vita Sancti Martini as its source, the image diverges significantly from this textual account. ${ }^{4}$ According to Sulpicius, as Martin was at prayer in his cell one day, the devil appeared, preceded by a purple light, smiling calmly, and wearing a royal robe, a jeweled crown, and golden shoes in an effort to persuade Martin that he was Christ. Martin remained undeceived, retorting, "The Lord Jesus did not predict that he would come dressed in purple or wearing a shining crown. I will not believe that Christ has come unless I see him in the same clothing and form in which he suffered, and unless he displays the marks of the cross." 5 At this, the devil vanished "like smoke" (ut fumus), leaving behind a disgusting smell that confirmed his true nature. ${ }^{6}$

The León painting differs most obviously from this account in its portrayal of the devil. Satan's painted robe here is white, rather than the purple referred to in the text; he wears no crown; and his feet are bare, not shod in gold. Moreover, his undersized body, dark brown skin, and exaggerated physiognomy,

3 See, for example, Walker, "Wall Paintings," 209-210. On the iconography of Saint Martin, see Yossi Maurey, Medieval Music, Legend, and the Cult of Saint Martin (New York: Cambridge University Press, 2014), 207-215; Etelvina Fernández González, "San Martín de Tours en el Camino de Santiago: culto, advocación e iconografía en la Edad Media," in El Camí de Sant Jaume i Catalunya: actes del Congrés Internacional celebrat a Barcelona, Cervera i Lleida, els dies 16, 17 i 18 d'octubre de 2003 (Abadia de Montserrat: Consejo Superior de Investigaciones Científicas, 2007), 221-238, esp. 228-238; and Agustín Gómez Gómez and Miguel Ángel Asiáin Yárnoz, "Caritas y diabolus en la iconografía de San Martín: el caso de San Martín de Unx (Navarra)," Príncipe de Viana 56/205 (1995): 283-310.

4 Among the first to explore the link to Sulpicius was John Williams, "Marcialis Pincerna and the Provincial in Spanish Medieval Art," in Hortus Imaginum: Essays in Western Art, ed. Robert Enggass and Marilyn Stokstad (Lawrence, KS: University of Kansas, 1974), 29-36, at 36 n.24.

5 Goodrich, Sulpicius Severus, 50; "Non se, inquit, Iesus dominus purpuratum nec diademate renidentem uenturum esse predixit; ego Christum, nisi in eo habitu formaque qua passus est, nisi crucis stigmata praeferentem, uenisse non credam." Fontaine, Vie de Saint Martin, 1:308 (24:7).

6 Fontaine, Vie de Saint Martin, 1:308. 
which call to mind western medieval conventions for sub-Saharan Africans, sit oddly beside Sulpicius's assertion that Satan's appearance was unexceptionalthat "there was nothing he resembled less than the devil." 7 None of this is easily explained by reference to established visual conventions either in Iberia or elsewhere in western Europe, and few scholars have gone further than to note them. ${ }^{8}$ The questions that they raise, however, remain essential to understanding the culture and world view that surrounded San Isidoro in this moment. Why did the unknown artist choose to depict Satan as a human with African-looking features? On what visual traditions did this image draw, and what meanings would its viewers have found in it? Finally, what implications would such meanings have held in the context of a Leonese rulership that, as the treasury objects themselves also indicate, was preoccupied in both positive and negative ways with the heterogenous peoples and cultures it envisioned beyond its borders?

The present essay approaches these questions in two stages: first by excavating the visual and textual traditions on which the artist drew, and then by considering their reception by those who frequented the vaulted lower level of the Leonese palace. It will argue that, far from a simple deviation from a presumed source text, the Martin scene at León was deliberately and quite inventively concocted from multiple, unrelated iconographic traditions, the complementary valences of which contributed critically to its meaning for viewers steeped in the world view of an ambitious and increasingly cosmopolitan Iberian capital. Eschewing the flat analysis of bygone iconographic study, it will pursue an intervisual model that recognizes the artist's engagement with a wide network of images, texts, and ideas circulating in early twelfth-century León while also exploring the polyvalency with which the image itself could speak to its viewers. ${ }^{9}$ To do so, as we shall see, offers a deeper understanding of how both artist

7 “... ut nihil minus quam diabolus putaretur ...;" Fontaine, Vie de Saint Martin, 1:308 (24:4). Translation by Evan White; Goodrich's "no one would believe he was the devil" (Sulpicius Severus, $5^{\circ}$ ) fails to convey the centrality of Satan's visual appearance to the deception.

8 The figure rarely earned more than passing comment by scholars before 1990, when Yarza described what he called the "negroid" features of the figure as drawing on their negative medieval associations; see Joaquín Yarza Luaces, "La présence du diable dans l'art espagnole: forme, déguisement, role," in Démons et merveilles au moyen âge: actes du IVe Colloque international, ed. Denis Menjot and Benoît Cursente (Nice: Université de Nice-Sophia Antipolis, 1990), 195-241, at 204. Gómez and Asiáin ("Caritas et diabolus," 297) also explained the figure's small size and color as generically negative features. Walker's and Martin's analyses are discussed below.

9 On intervisuality, see Michael Camille, "Gothic Signs and the Surplus: The Kiss on the Cathedral," Yale French Studies, special issue, Contexts: Style and Values in Medieval Art and Literature (1991): 151-170, at 151. 
and viewers construed their world and the great cultural project of which the paintings were just one part.

\section{Satan's Blackness}

Satan's physical appearance stands at the crux of this inquiry. He is not simply black in hue, as were many medieval depictions of the devil, nor does he conform to the monstrous, often hybridized physical convention typically employed for such figures at this time. Instead, his brown skin, low-bridged nose, full lips, and enlarged white eye invoke a specifically human type, one that a western medieval viewer might have called an Aethiops, or Ethiopian. Already well developed in ancient art to represent the Africans of various origin with whom Greek and Roman communities came into contact through trade and travel, ${ }^{10}$ the Ethiopian topos as it emerged in the medieval west would distill the features traditionally perceived as characteristic of Africans into a stereotype featuring dark brown, black, or blue skin; curly hair; full lips; a rounded or low-bridged nose; oversized eyes; and occasionally a short goatee (Figure 7.2). ${ }^{11}$

The medieval stereotype of the Ethiopian was not merely more abstract than its forerunners: its signification was more expansive, in that it could refer to virtually any dark-skinned, foreign, or exotic people hailing from multiple locations outside Europe, including India, Egypt, and other parts of Africa. ${ }^{12}$ These also included several kinds of Ethiopians located there by Classical texts, including the "four-eyed Ethiopians" (Maritimi or Nisitae) reported there by Pliny the Elder, the barbaric "Ethiopians" described by Hanno farther to the

10 For an overview of this tradition and its checkered historiography, see Jeremy Tanner, "Introduction to the New Edition. Race and Representation in Ancient Art: Black Athena and After," in The Image of the Black in Western Art, Volume I: From the Pharaohs to the Fall of the Roman Empire, ed. David Bindman and Henry Louis Gates (Cambridge, MA: Belknap Press, 2010), 1-39.

11 On medieval visual stereotypes of the Ethiopian, see Dorothy Hoogland Verkerk, "Black Servant, Black Demon: Color Ideology in the Ashburnham Pentateuch," Journal of Medieval and Early Modern Studies 31/1 (2001): 57-77; Debra Strickland, Saracens, Demons, and Jews: Making Monsters in Medieval Art (Princeton: Princeton University Press), 37-39, and Strickland, "Monstrosity and Race in the Late Middle Ages," in The Ashgate Research Companion to Monsters and the Monstrous, ed. Asa Simon Mittmann and Peter Dendle (Farnham, UK: Ashgate, 2012), 363-386.

12 This idea was already incipient in ancient literature, as noted by J.W. Gardner, "Blameless Ethiopians and Others," Greece \& Rome 24/2 (1977): 185-193. 


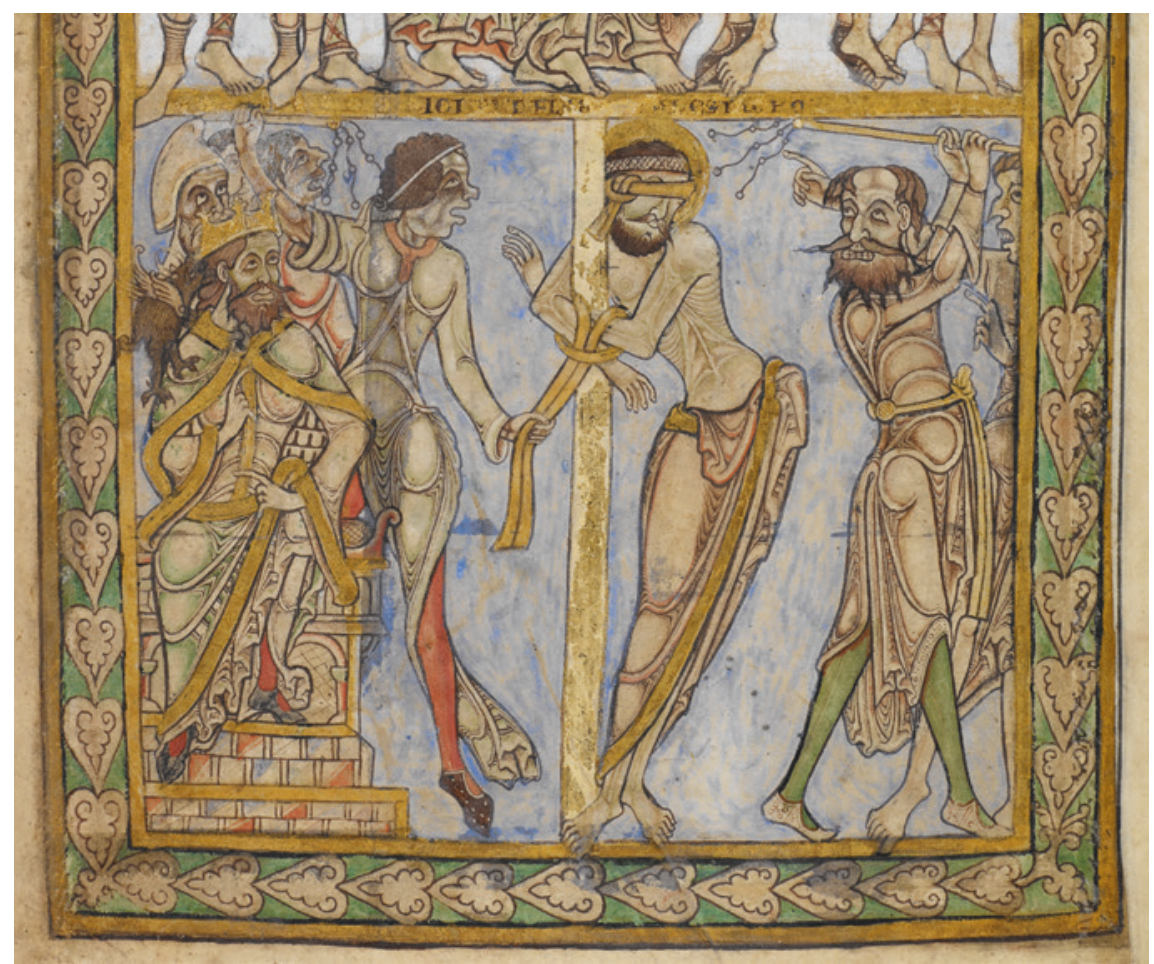

FI GURE 7.2 Detail: Flagellation of Christ, Winchester Psalter (London, British Library, Cotton MS Nero C IV), fol. $21 r$.

PHOTO (C) BRITISH LIBRARY BOARD, COTTON MS NERO C IV

west, and a host of still more fantastical beings. ${ }^{13}$ Their relative independence from the realities of the medieval world endowed these figures with broad symbolic potential that drew heavily on the negative connotations attached to the topos by ancient authors, which included sensuality, primitivism, cowardliness, and aggression. ${ }^{14}$ In monastic writing in particular, these properties

13 In addition to the Maritimi, Pliny also assigned many so-called Monstrous Races to Ethiopia; see John Block Friedman, The Monstrous Races in Medieval Art and Thought (Syracuse, NY: Syracuse University Press, 2000), 8. On Hanno, see Gardner, "Blameless Ethiopians," 185 .

14 Strickland, Saracens, Demons, and Jews, 79-93; Friedman, Monstrous Races, 54-55, 64-65; on specifically religious applications of the stereotype, see Jean Devisse, "Christians and Black," in The Image of the Black in Western Art. 2. From the Early Christian Era to the "Age of Discovery." Part 1. From the Demonic Threat to the Incarnation of Sainthood, ed. David Bindman and Henry Louis Gates (Cambridge, MA: Belknap Press, 2010), 46-55. The occasional "positive" black figures of medieval culture, such as the Queen of Sheba and St. 
contributed to a generalized tradition in which sinful Ethiopian blackness could only be "whitened" by conversion to a Christian life. ${ }^{15}$

From such foundations, it was only a short leap to describing Satan and his representatives as Ethiopian themselves, a strategy exemplified by Athanasius's well-known fourth-century Life of Saint Anthony, which describes how, after failing to tempt the saint in other forms, the devil took the form of an Ethiopian boy and identified himself as the spirit of fornication. ${ }^{16}$ Other early monastic writers reported similar encounters: Gregory the Great's Dialogues, for example, describe a certain monk's inability to get through his prayers because the devil, disguised as a small black boy, kept tugging on his cloak. ${ }^{17}$ The same trope persisted in later medieval texts: Rodulfus Glaber's many references to demons include "black Ethiopians" whose appearance signaled the presence of false relics, while Peter the Venerable attributed a monk's distraction during prayer to a small Ethiopian who was shooting arrows at him in his cell. ${ }^{18}$ Such accounts substantiate Peter Brown's crisp observation that "there is hardly a saint in medieval Europe whose temptations are not modeled on those first described in connection with Anthony on the outskirts of an Egyptian village." 19

Maurice, seem to have been seen as exceptions proving the rule; on these, see Madeline Caviness, "(Ex)changing Colors: Queens of Sheba and Black Madonnas," Architektur und Monumentalskulptur des 12-14 Jahrhunderts: Produktion und Rezeption. Festschrift für Peter Kurmann zum 65. Geburtstag (New York: Peter Lang, 2006), 553-570; Gude Sukale-Redlefsen, Mauritius: Der heilige Mohr. The Black Saint Maurice (Houston: Menil Foundation, 1987); and Jean Devisse, "A Sanctified Black: Maurice," in The Image of the Black. 2. From the Early Christian Era to the "Age of Discovery." Part 1. From the Demonic Threat to the Incarnation of Sainthood, ed. David Bindman and Henry Louis Gates (Cambridge, MA: Belknap Press, 2010), 139-194.

15 See Jean-Marie Courtès, "The Theme of 'Ethiopia' and 'Ethiopians' in Patristic Literature," in The Image of the Black. 2. From the Early Christian Era to the "Age of Discovery." Part 1. From the Demonic Threat to the Incarnation of Sainthood, ed. David Bindman and Henry Louis Gates (Cambridge, MA: Belknap Press, 2010), 199-214; Gay L. Byron, Symbolic Blackness and Ethnic Difference in Early Christian Literature (London: Routledge, 2002), 55-76.

16 Athanasius, The Life of Anthony and the Letter to Marcellinus, trans. Robert Gregg (New York: Paulist Press, 1980), 33-35.

17 The Dialogues of Gregory the Great. Book Two: Saint Benedict, trans., intro., and notes by Myra L. Uhlfelder (Indianapolis: Bobbs-Merrill, 1967), 10-12.

18 Rodulfus Glaber, The Five Books of the Histories, 4:3:7-8, ed. and trans. John France (Oxford: Clarendon Press, 1989), 184-185; Petri Cluniacensis Abbatis, De miraculis Libri Duo, ed. Dyonisia Bouthillier (Turnhout: Brepols, 1988), 32-33 (I, 8).

19 Peter Brown, The World of Late Antiquity, A.D. ${ }^{150-750}$ (New York: Harcourt Brace Jovanovich, 1971), 99-100. See also Gregorio Penco, "Sopravvivenze della demonologia antica nel monachesimo medievale," Studia Monastica 13/1 (1971): 31-36. 
In light of this long tradition, the Leonese artist's choice of a small "Ethiopian" Satan to tempt St. Martin would seem a natural choice, as perhaps already had occurred to San Isidoro's longtime historian, Antonio Viñayo González, when he described the devil's form as that of a "black dwarf" (un enano negro). ${ }^{20}$ Yet this representation remains an unicum in Martin's textual and visual hagiography to this point. None of Martin's surviving vitae from the fifth to twelfth centuries makes reference to Satan as either black or Ethiopian, and visual narratives of the saint's life offer few useful comparanda. ${ }^{21}$ Nor does Iberian art more generally: beyond the rare exceptions to be discussed below, Iberian images of the devil in this period tended to adhere to the monstrous, hybrid type traditional elsewhere in western Europe. ${ }^{22}$ Several such figures appear in the Hell scene produced for the Silos Beatus circa 1109 (London, BL, MS Add. 11695, fol. 2r), a work close in date and provenience to the León image: their light-colored, oddly spotted faces top dark bodies with claw feet, horns or flamelike (in one case curly) hair, and sometimes a tail (Figure $7 \cdot 3$ ). ${ }^{23}$

$20 \quad$ Viñayo, Panteón de los Reyes, 47.

21 A review of the vitae from the fifth to twelfth centuries reveals no references to the devil in this episode as appearing as a black man. A sixth-century account by Venantius Fortunatus briefly cites the role of "the black devil's art" in the attempted deception of the young monk Clarus that just precedes the Satan episode, but this reference seems more metaphorical than literal and does not extend into Fortunatus' account of Martin's temptation. See Venantius Fortunatus, De vita Sancti Martini (PL 88:363-426). For other vitae, see Clare Stancliffe, St. Martin and His Hagiographer: History and Miracle in Sulpicius Severus (Oxford: Oxford University Press, 1984), 235-236, and the online Société des Bollandistes Bibliotheca Hagiographica Latina Manuscripta (http://bhlms.fltr.ucl.ac.be/; accessed o1/15/19). Visual depictions of Martin's temptation at prayer remain elusive in the eleventh and twelfth centuries, and even more common scenes featuring the saint's encounter with the devil, such as his meeting with the devil in the road or the devil's appearance at his deathbed, offer little precedent for the black devil at León.

22 Joaquín Yarza has published extensively on the general iconography of the devil in Iberian art: see in particular Joaquín Yarza Luaces, "Del ángel caído al diablo medieval," Boletín del Seminario de Estudios de Arte y Arqueología 45 (1979): 299-316; Yarza, "La présence du diable dans l'art espagnole," 195-241; and Yarza, "El diablo en los manuscritos monásticos medievales," Codex Aquilarensis: Cuadernos de Investigación del Monasterio de Santa María la Real 11 (1994): 103-130. See also Esperanza Aragonés Estella, La imagen del mal en el románico navarro (Pamplona: Gobierno de Navarra, 1996), 36-38.

23 On this manuscript, see John Williams, The Illustrated Beatus: A Corpus of Illustrations of the Commentary on the Apocalypse, 5 vols. (London: Harvey Miller, 1994-2003), 4:31-40; Visions of the End in Medieval Spain: Catalogue of Illustrated Beatus Commentaries on the Apocalypse and Study of the Geneva Beatus, ed. Therese Martin (Amsterdam: Amsterdam University Press, 2017), 112-115. On the Hell scene, see Meyer Schapiro, "From Mozarabic to Romanesque in Silos," Art Bulletin 21 (1939): 313-374. 


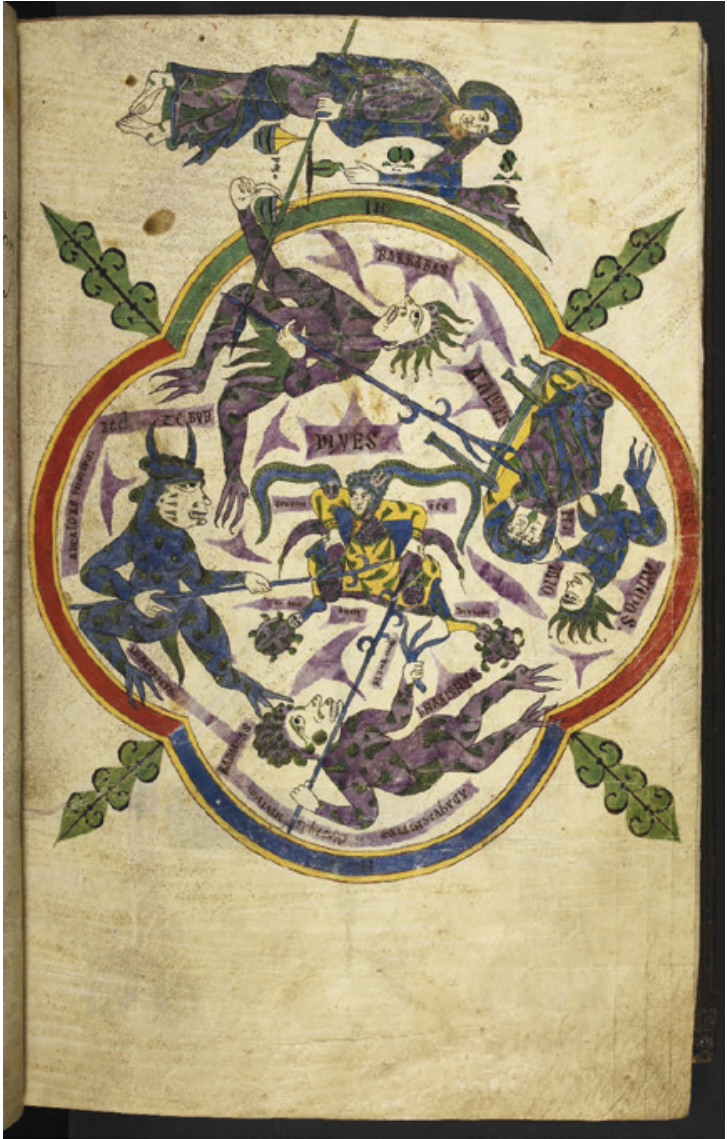

FIGURE 7.3

Hell, Silos Beatus (London, BL, Add. MS 11695), fol. 2 r. SOURCE: PHOTO DEDICATED TO THE PUBLIC DOMAIN AND REPRODUCED UNDER A CCO 1.0 UNIVERSAL LICENSE

Confronted with this well-established tradition, one might well ask what led the Leonese painter instead to adapt the distant textual convention of the Ethiopian Satan to this apparently new iconographic context, and what meanings would it have conveyed here. Addressing these questions requires a closer look at the visual roots of the St. Martin scene as a whole. As we shall see, these lay not in any one single model for the composition per se, but in a distinctive combination of elements from several largely unrelated visual traditions, the combination of which was tailored uniquely to the painting's cultural setting.

\section{$2 \quad$ Satan as Tempter and Adversary from the Gospels to End Times}

Satan's posture and gestures in the León scene are nearly as distinctive as his physical appearance (see Figure 7.1). Looking intently toward St. Martin, he 
points sharply downward with his right hand while the left crosses his body to point upward toward the saint. Nothing in Martin's vitae or visual tradition explains his chiastic gesture, but parallels do appear in a largely unrelated context: eleventh- and twelfth-century European depictions of the three Temptations of Christ. In such images, which draw upon Byzantine traditions of somewhat earlier date, Satan often makes a similar gesture when he addresses the savior, usually in the second Temptation when, on the pinnacle of the Temple, he offers the riches of the world in exchange for Christ's adoration of him. ${ }^{24}$ Widely dispersed throughout western Europe after 110o, this variant had certainly reached north-central Iberia by the second quarter of the twelfth century, since it appears in a fresco of the Temptations of Christ from San Baudelio de Berlanga (Soria), now in the Metropolitan Museum of Art (Figure 7.4). Here, in a scene conflating the second and third Temptations, the centrally-placed, dark, goat-headed Satan points toward Christ with his left hand as his right gestures downward. ${ }^{25}$

The León figure compares well with that from San Baudelio, even preserving Satan's pointing gesture with his "sinister" hand despite the pair's reversed positions. However, its link with the Christological tradition is made still clearer by its inscription, $\mathrm{s}[\mathrm{AN}] \mathrm{C}[\mathrm{TU}] \mathrm{s}$ MARTINUS DIXI[T] VADE SATANAS. This command, although lacking from Martin's surviving vitae, echoes Christ's response to Satan after he is tempted for the third time (Mt. 4:10): "Tunc dicit ei Jesus: Vade Satana" (Then Jesus saith to him: Begone, Satan). ${ }^{26}$ The Gospel passage itself is sometimes paired with Satan's pointing gesture in other Romanesque scenes of the Temptation, such as the late eleventh-century Gospels of Matilda of Tuscany (Pierpont Morgan Library, MS M. 492, fol. 43v; Figure 7.5). ${ }^{27}$ Its near-repetition at León implies not only an awareness of this prior tradition, but a sensitivity to its symbolic potential: in setting the frontal, Christ-like

24 I thank Jaroslav Folda for his insights on this point. Exemplifying the Byzantine formula in migration are the Temptation scenes in the south vault of San Marco in Venice; see Otto Demus, The Mosaic Decoration of San Marco, ed. Herbert Kessler (Chicago: University of Chicago Press, 1988), 43 and pl. 9 b.

25 Milagros Guàrdia Pons, San Baudelio de Berlanga, una encrucijada (Bellaterra: Universitat Autónoma de Barcelona, 2011), 330-338 and pl. 19. For another Iberian example, see Vasanti Kupfer, "The Iconography of the Tympanum of the Temptation of Christ at The Cloisters," Metropolitan Museum Journal 12 (1977): 21-31.

26 Biblical Latin quotations are taken from the Vulgate: Biblia sacra iuxta vulgatam Clementinam. Nova editio logicis partitionibus aliisque subsidiis ornata a Alberto Colunga et Laurentio Turrado, 6th ed. Biblioteca de autores cristianos, 14 (Madrid: Ed. Católica, 1982). English passages are from the Douay-Rheims Bible.

27 Robert H. Rough, The Reformist Illuminations in the Gospels of Matilda, Countess of Tuscany (A Study in the Art of the Age of Gregory VII) (The Hague: Nijhoff, 1973). 


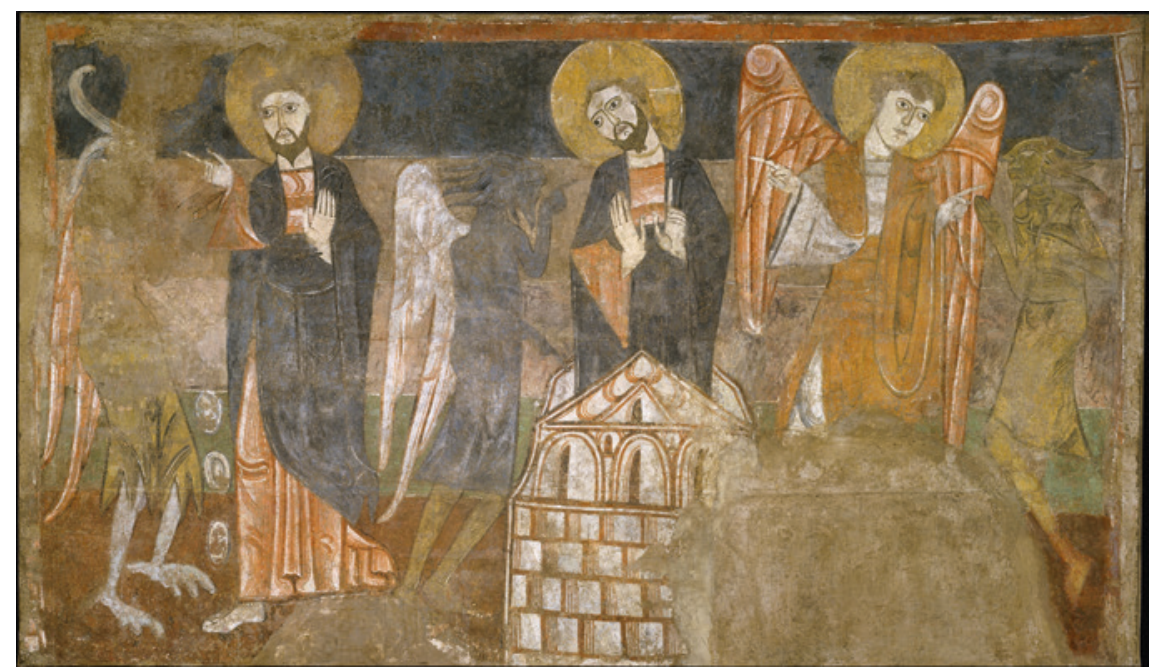

FIGURE 7.4 Temptations of Christ from San Baudelio de Berlanga (New York, Metropolitan Museum of Art, 61.248).

SOURCE: PHOTO DEDICATED TO THE PUBLIC DOMAIN AND REPRODUCED UNDER A CCO 1.0 UNIVERSAL LICENSE

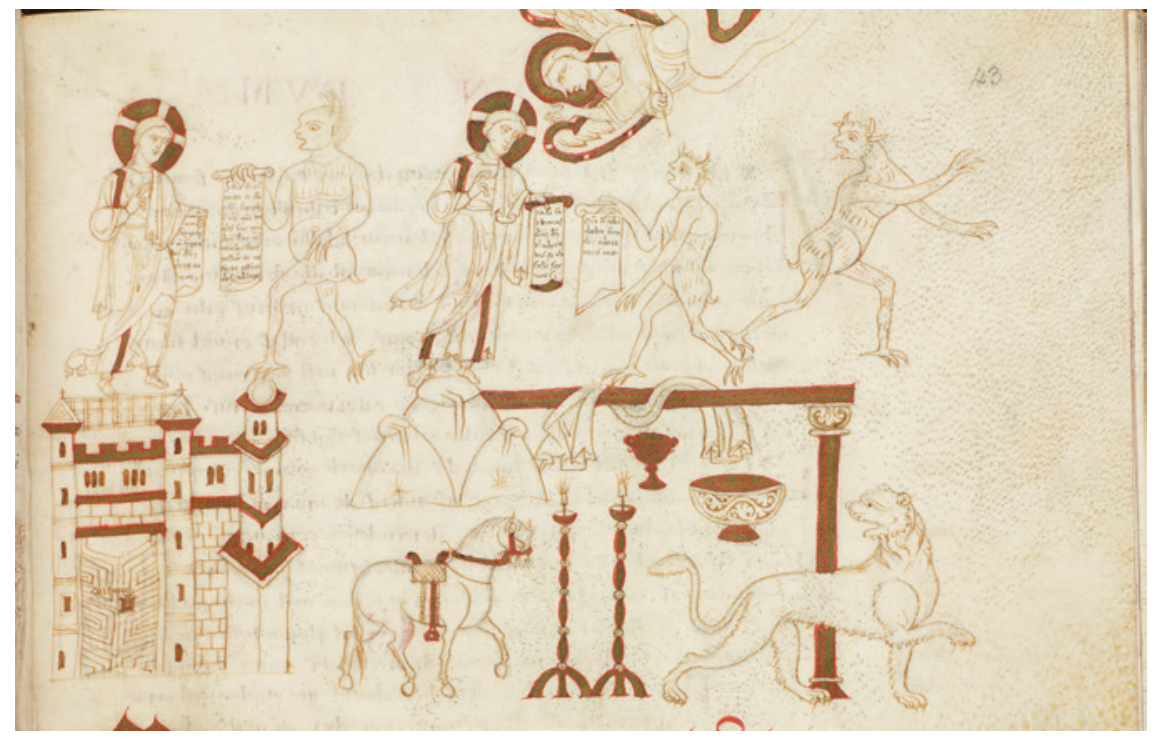

FIGURE 7.5 Second Temptation of Christ, Gospels of Matilda of Tuscany (New York, J. Pierpont Morgan Library \& Museum, MS M. 492), fol. 43v. PHOTO: THE PIERPONT MORGAN LIBRARY, NEW YORK 
Martin, with his pale, serene visage and blessing hand, in opposition to a dark, stereotyped adversary, the artist associates the saint's forbearance with that of his divine exemplar.

If this compositional model helps to clarify some elements of the León imagery, it does little to explain its most notable feature: the portrayal of Satan with Ethiopian features. For this, the most promising visual precedent is a local one: that most Iberian of genres, the illustrated Beatus. Composed around 776 in Asturias, Beatus of Liebana's original Commentary on the Apocalypse was copied repeatedly between the tenth and thirteenth centuries, forming a closely related series of manuscripts with over 100 canonical illustrations each; ${ }^{28}$ several of these, all produced in or near León during the tenth and eleventh centuries, contain images relevant to the Panteón devil. They include the Morgan Beatus (Morgan Library and Museum, Ms M. 644), produced by Maius circa 940, likely in Tábara; ${ }^{29}$ the Beatus of Fernando I and Sancha (Madrid, Biblioteca Nacional de España, MS vitr. 14/2), made in León in 1047 and sometimes called the Facundus Beatus after the scribe who signed it on that date; ${ }^{30}$ and the Burgo de Osma Beatus (Burgo de Osma Cathedral, Ms. 1), signed in 1086 by Martinus and most likely made at the royally sponsored Leonese monastery of Sahagún. ${ }^{31}$

Satan is central to three of the canonical illustrations shared by these manuscripts. That for Apoc. 12:1-18, depicting the Woman Clothed in the Sun, shows him bound in hell with his followers; that for Apoc. 20:1-3 depicts him chained in the abyss; and that for Apoc. 20:9-10 portrays him in the Lake of Fire. In all of these he takes the form not of a monstrous hybrid, but of a black human male. In the Morgan Beatus illustration of Apoc. 12:1-18, he is coal-black and humanoid, sharing the somatotype and extremities of the pale-skinned figures that surround him in hell; and despite abrasion to the face, several rounded curls and the tip of a pointed beard suggest an Ethiopian stereotype (Figure 7.6). ${ }^{32} \mathrm{In}$ the illustration of Apoc. 12:1-18 (fol. 187r) in the Beatus of Fernando and Sancha,

28 For background and bibliography on each manuscript, see Williams, Corpus; a cogent introduction to the Beatus tradition and more recent bibliography are found in Williams, Visions of the End, esp. 21-66 and 273-284.

29 Williams, Corpus, 2:21-33; Williams, Visions of the End, 69-72. See also A Spanish Apocalypse: The Morgan Beatus Manuscript, intro. and commentaries by John Williams; codicological analysis by Barbara A. Shailor (New York: Braziller, 1991).

$30 \quad$ Williams, Corpus, 3:34-40; Williams, Visions of the End, 96-99; see also Beato de Fernando Iy Sancha (Barcelona: Moleiro, 2006).

31 Williams, Corpus, 4:17-25; Williams, Visions of the End, 105-109. A new facsimile has recently appeared: Peter K. Klein, El Beato de Burgo de Osma, s. XI (Valencia: Scriptorium, 2016).

32 Yarza early connected the introduction of dark color and humanoid elements to Maius in the Morgan Beatus but did not connect them specifically with the Ethiopian topos. 
the type is better preserved: Satan's black body is outlined in red and stretched long, its naturalistic hands and feet curled slightly as they struggle against their bonds; his face, shown in profile, displays a large eye and flat-bridged nose, while his hair falls behind him in wiry locks (Figure 7.7). ${ }^{33}$

The illustrations of the Fernando and Sancha Beatus are particularly relevant to the painting at León, where the manuscript seems to have remained after its royal patrons' deaths and might still have been accessible to the painter of the Panteón de los Reyes over half a century later. In fact, the presence of several inscriptions shared in common between this Beatus and the Panteón's painting of the Vision of Saint John led John Williams to suggest that the artist might have copied them directly from the manuscript, while Rose Walker identified several formal elements in the same scene as traceable to the Beatus tradition. ${ }^{34}$ If the manuscript was in fact available to the later artist, it is possible to imagine its stereotyped devils inspiring the Ethiopianized Satan of the St. Martin scene.

Access to this specific manuscript was perhaps not necessary, however, since by the end of the eleventh century, an Ethiopianized Satan had begun to appear in other Beatus manuscripts in the same region. The most notable of these is the Burgo de Osma Beatus, produced in the monastery of Sahagún, a favorite residence of King Alfonso VI (r. 1065-Jan 1072; Oct 1072-1109), which lay two days' journey from the capital itself. ${ }^{35}$ The Osma codex shares with the earlier Beatuses the inclusion of an Ethiopian devil in the three scenes already mentioned, but it also inserts such figures into two further illustrations: Apoc. 20: 7-8, in which Satan tempts Gog and Magog, and Apoc. 20: 11-15, where two Ethiopian demons with gaping mouths

See Joaquín Yarza Luaces, "Diablo e infierno en la miniatura de los Beatos," Actas del Simposio para el estudio de los códices del "Comentario al Apocalipsis" de Beato de Liébana (Madrid:Joyas Bibliográficas, 1976), 2:231-255, esp. 239. As observed by Gómez and Asiáin ("Caritas y diabolus," 297), such figures resemble late Antique types and likely were derived from these.

33 The Satan figures in Apoc. Xx, 1-3 and 9-10 (fols. 243v and 249v) display a similar physiognomy, although with more claw-like hands and feet.

34 Williams, Corpus, 1:99-100, and Williams, "León: The Iconography of a Capital," in Cultures of Power: Lordship, Status, and Process in Twelfth-Century Europe, ed. Thomas N. Bisson (Philadelphia: University of Pennsylvania Press, 1995), 231-258, esp. 254; Walker, "Panteón de los Reyes," 217.

35 On the localization to Sahagún, see Barbara Shailor, "The Beatus of Burgo de Osma: A Paleographical and Codicological Study," in Apocalipsis Beati Liebanensis: Burgo Oxomensis. 2. El Beato de Osma: Estudios (Valencia: Vicent García, 1992), 29-52. See also Williams, Corpus 4:21-23. 


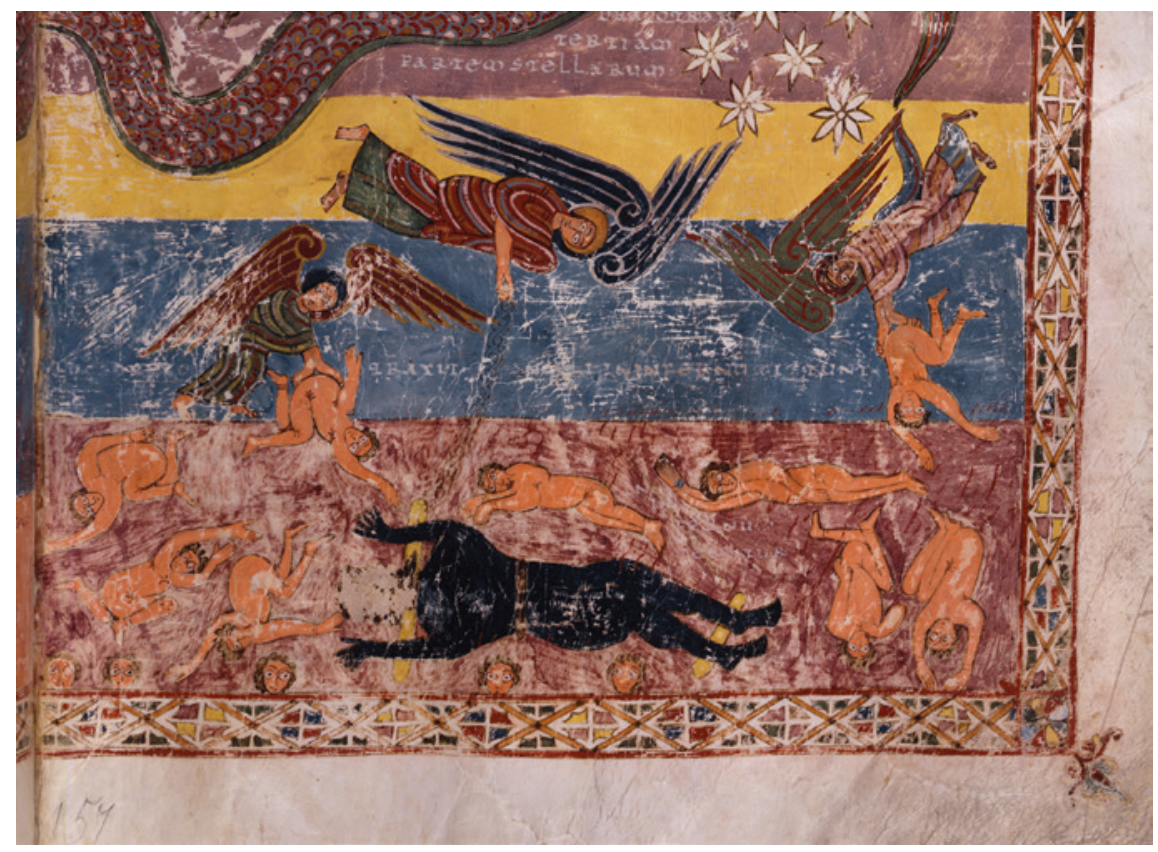

FIGURE 7.6 Detail of Satan, from the illustration of Apoc. XII:1-18, Morgan Beatus (New York, J. Pierpont Morgan Library \& Museum, MS M. 644) fol. 153r. PHOTO: THE PIERPONT MORGAN LIBRARY, NEW YORK

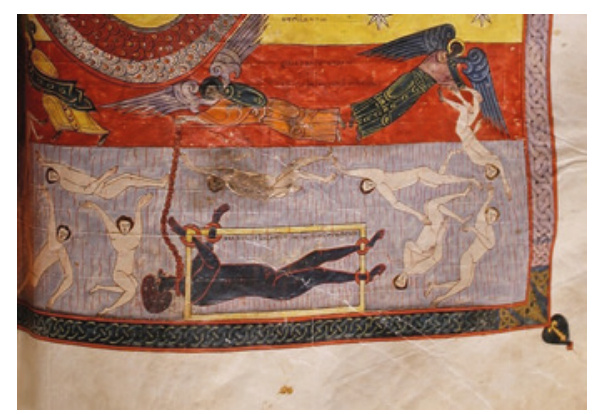

\section{FIGURE 7.7}

Detail of Satan, from the illustration of Apoc. XII: 1-18, Beatus of Fernando I and Sancha (Madrid, Biblioteca Nacional de España, MS vitr. 14/2), fol. 187r.

PHOTO: HAMID SHAMS

project their heads into a scene of the Last Judgment. ${ }^{36}$ Most notable is the Gog and Magog scene, where the traditional seven-headed beast representing Satan has been replaced by the most fully conceived Ethiopian figure of the entire Beatus tradition (Figure 7.8). His coal-black body is carefully

36 Yarza ("Diablo e infierno," 240-241) connects the proliferation of devils in Beatus illustrations at this time to an increased monastic concern with figures of evil. The inscription in the margin is from the Apocalypse (20:13): "mors et infernus dederunt mortuos suos." 


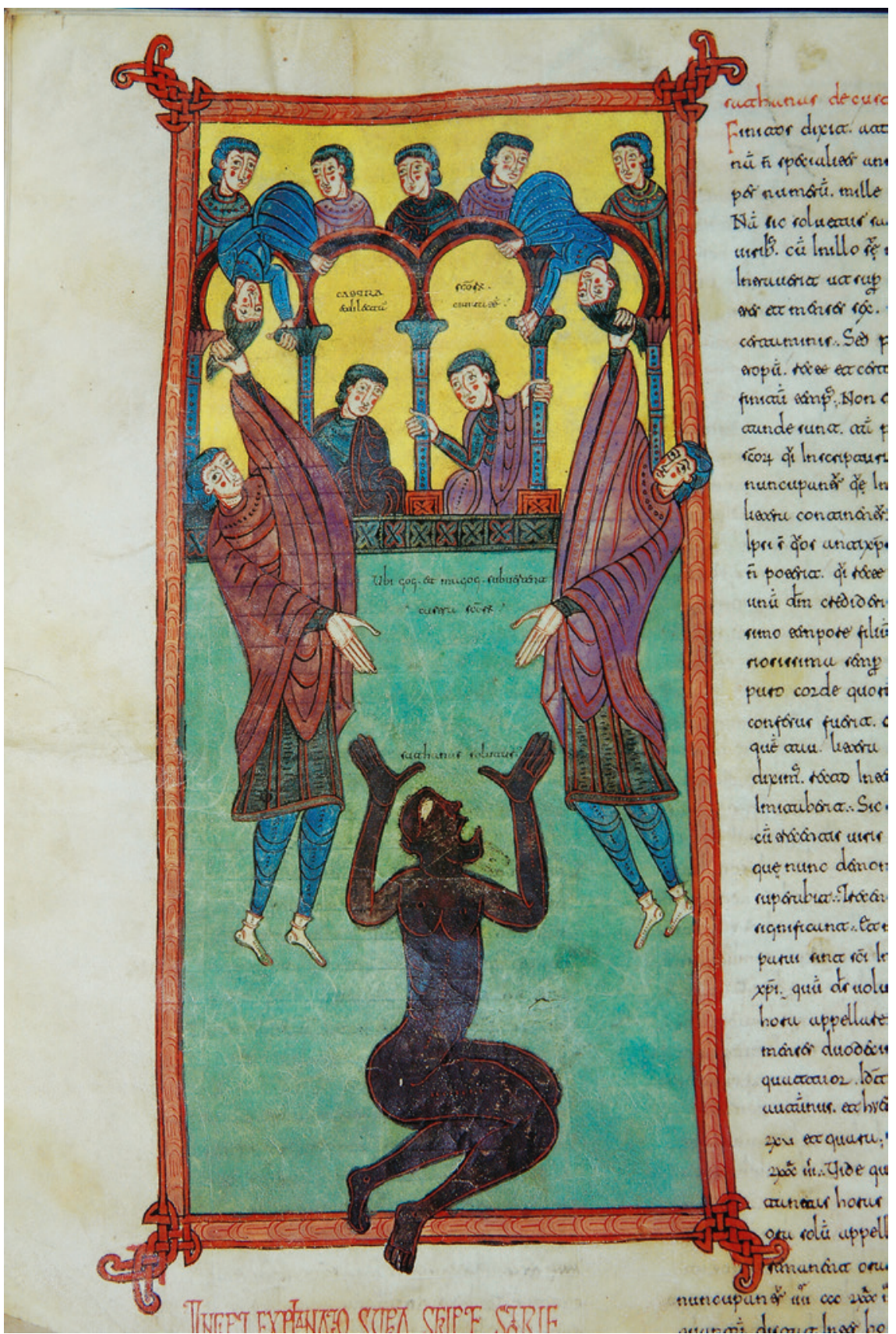

FIGURE 7.8 Temptation of Gog and Magog, from the illustration of Apoc. XX, 7-8, Burgo de Osma Beatus (Burgo de Osma Cathedral, Ms 1), fol. 155v.

PHOTO: HAMID SHAMS 
proportioned, his shoulders and hands turned gracefully in space, and his profile face, with its snub nose, spiky hair, and large eye, effectively prefigures that of the León painting.

The Osma figure confirms that the Ethiopian stereotype enjoyed at least some dissemination within the environs of León by the end of the eleventh century. Moreover, it also suggests the additional meanings that such a figure might have accrued. In replacing the traditional seven-headed beast of the Gog and Magog scene with an Ethiopian, Martinus chose to emphasize the theme of temptation inherent in this stereotype, highlighting its suitability to a new context in which Satan, freshly loosed from his bonds, would "go forth, and seduce the nations, which are over the four quarters of the earth, Gog, and Magog" (Apoc. 20:7). Presenting Satan in this form recalled his well-worn habit of disguising himself to tempt the faithful. However, it also drew slyly on this strategy's transparency, since in many monastic narratives, it was the very sight of an Ethiopian, whether tugging at a monk's clothing or clambering out of a reliquary, that alerted Satan's victims to his presence and intent. By replacing the beast with the Ethiopian in the Burgo de Osma image, Martinus forged a double entendre that simultaneously revealed the very identity that it purported to conceal. ${ }^{37}$

A similar visual strategy animates the Temptation at León: Satan's small stature and dark, foreign countenance play dramatically against the royal robes with which he aims to deceive St. Martin, alerting the viewer to his identity even before it is acknowledged by the saint. Satan's failure in this case is, of course, critical to the success of the narrative, which centers on Martin's adeptness at seeing through the ploy. As Sulpicius Severus pointed out, recognizing the devil in all his disguises was one of the saint's most remarkable abilities: "... the devil was always visible and apparent to his eyes, so that, whether he confined himself to his proper substance or whether he transformed himself into various figures of spiritual wickedness, Martin always perceived him, no matter what form he took." 38 Like the foul smell in Martin's vitae, an effect with no visual translation, Satan's Ethiopian disguise offered a signpost in the narrative that few medieval viewers were likely to miss.

37 On the value of this strategy in similar contexts, see Béla Zsolt Szakács, "Supernatural Figures Incognito," in Angels, Devils. The Supernatural and Its Visual Representation, ed. Gerhard Jahritz (Budapest: CEU Press, 2011), 75-91, esp. 9 o.

38 Goodrich, Sulpicius Severus, 46; "Diabolum vero ita conspictabilem et subjectum oculis habebat ut, sive se in propria substantia contineret, sive in diversas figuras nequitiae transtulisset, qualibet ab eo sub imagine videretur." Fontaine, 1:298 (21:1). 
The iconographic strands central to St. Martin's Temptation at León clearly offered meanings at multiple levels. Echoing the familiar compositions of Christ's own Temptation, they revealed the divine exemplar on whom the saint modeled his patient resistance; evoking the Ethiopian devils of both monastic legend and the Beatus tradition, they exhorted the viewer to guard against Satan's penchant for disguise. Yet for a twelfth-century Iberian viewer in the capital of what was then the Iberian peninsula's most ambitious Christian-ruled kingdom, the devil's unusual appearance also might have raised other, less traditionally rooted associations. The most intriguing has previously been raised by Rose Walker and Therese Martin, who in separate publications suggested that Satan figure's brown skin and distinctive facial features would have raised associations with Iberian Muslims. Walker saw the dark skin and unusual dress of the Satan figure as calling to mind the Almoravid Muslims who held power to the south of León's borders at this date; Martin proposed that it alluded to a specific Muslim individual: Zaida, the concubine and eventual wife of Queen Urraca's father Alfonso VI, to whom she had borne Urraca's half-brother and erstwhile rival Sancho. ${ }^{39}$

Both scholars are correct in identifying an increased concern with Muslims in León at this time. Following King Fernando I's consolidation of the kingdom between 1037-1065, King Alfonso VI had adopted an aggressive stance toward the disorganized taifas to his south, first enforcing the payment of tribute by, and then attacking, key Muslim-ruled cities, among them Toledo, conquered on 6 May 1085. This last victory prompted the taifa rulers of Sevilla, Granada, and Badajoz to request aid from the Almoravid emir in Morocco, Yusuf ibn Tashufin, who stopped Alfonso's conquests in their tracks, annexing the

39 On Zaida, see Bernard Reilly, The Kingdom of León-Castilla under Queen Urraca (1109-1126) (Princeton: Princeton University Press, 1982), 25-26, and Alberto Montaner Frutos, "La mora Zaida, entre historia y leyenda (con una reflexión sobre la técnica historiográfica alfonsí)," in Historicist Essays on Hispano-Medieval Narrative. In Memory of Roger M. Walker, ed. Barry Taylor and Geoffrey West (London: Maney, 2005), 272-352. Walker ("Wall Paintings," 209) identified Satan's dark skin and "Arab dress" as key Muslim signifiers, while Martin (Queen as King, 149) read the figure as female, a possibility also hinted at by Yarza ("Presence du diable," 204) when he referred to it as "travesti." I have not found iconographic support for a reading of the figure as female: the robe is not gender-specific in design, and its straight fall lacks the fluidity of feminine garments elsewhere in the Panteón, while uncovered hair is quite rare in any female figure in Iberian art of this date. Since beardlessness and long hair were common signs of youthful masculinity, as exemplified by images of John the Evangelist above all, the figure is logically read as an Ethiopian boy consistent with those in the monastic texts. 
remaining taifas into a single, Muslim-ruled empire that, by 1102, stretched across the south of the Iberian peninsula from Badajoz to Valencia. ${ }^{40}$

The consolidation of Almoravid power just beyond Leonese borders certainly might have rendered a painted figure of Satan — or indeed of any biblical or legendary antagonist—ripe for negative references to Muslim culture. Yet the León figure's somatotype was likely not the main trigger for this. During the first decades of the twelfth century, the eventually familiar tradition of portraying Muslims with dark skin and African features was still unknown in northern Spain; very few such images can be identified unequivocally before the end of that same century. ${ }^{41}$ It is therefore unlikely that the stereotyped Ethiopian features of the figure at León would have provoked their original viewers to see the figure specifically as Muslim when, on the basis of skin color and facial type alone, they had reason to see it simply as an Aethiops.

This is not to suggest that the figure did not refer to Islamic culture at all, but to indicate that such references were effected in other, more subtle ways. One such signal is Satan's unconventional white robe, which so perplexingly contradicts its description in St. Martin's vitae. As has been noted, Martin's biographers concur in identifying the devil's robe as purple, a color entirely appropriate to a royal disguise. By contrast, the garment at León is not merely white, but distinctive in both cut and ornament. A straight, narrow robe with sleeves that widen at the ends, it is bordered at the neck, cuffs, and hem, as well as in a vertical strip down the front, by colored bands of ornament comprised of rounded, framed medallions between narrow borders of alternating circles. The result is a hybrid garment, consistent in shape with the elegant brial worn by elites of both genders in the twelfth-century Christian-ruled Iberian kingdoms, but of a color and ornament resembling the fine tịāz stuffs produced in Fatimid Egypt from the tenth through twelfth centuries. ${ }^{42}$

40 José María Mínguez Fernández, Alfonso VI: Poder, expansion y reorganización interior (Hondarribia:Nerea, 2000), esp. 87-107 and 131-177; Amira K. Bennison, The Almoravid and Almohad Empires (Edinburgh: Edinburgh University Press, 2016), 40-48; see also Bernard Reilly, The Kingdom of León-Castilla under Alfonso VI (1065-1109) (Princeton: Princeton University Press, 1988), 161-184, and Reilly, Kingdom of León-Castilla under Urraca, 12-32.

41 The Iberian examples cited by Inés Monteira are not always clearly Muslim rather than generically Africanized, and they cluster at the end of the twelfth century; see Inés Monteira Arías, El enemigo imaginado: la escultura románica hispana y la lucha contra el Islam (Toulouse: CNRS- Université de Toulouse-Le Mirail-Framespa, 2012), 482-484. On the late medieval tradition of depicting Muslims with dark skin, see Strickland, Saracens, Demons, and Jews, 173-182.

42 The garment was characterized simply as "Arab" by Walker ("Panteón de los Reyes," 209); its western cut was not noted. On the brial, see Carmen Bernis Madrazo, Indumentaria medieval española (Madrid: CsIC, 1956), 15-16. I am indebted to my Treasury Project 
Țirāz in its most conventional sense refers to textiles made of finely woven white cotton or linen, and in the most expensive cases linen and silk, ornamented with embroidered lines of Arabic inscription. ${ }^{43}$ Although țirāz textiles were produced in many Islamic centers, including al-Andalus, an especially strong tradition emerged in Cairo in the second half of the tenth century, and its more luxurious variations became a sartorial staple at the Fatimid court. ${ }^{44}$ The earliest Fatimid examples generally were white robes bearing simple bands of inscription, originally pious but often including the name of a ruler or his agents; by the end of the eleventh century, they might be embellished with tapestry-woven bands, sometimes worked with gilt thread, comprised of ornamental medallions within narrow lines of inscription. ${ }^{45}$ Especially comparable with the León image are the white linen exemplars produced in Cairo and Fustat in this period, best exemplified by the so-called "Veil of St. Anne," made in Damietta in 1097 and bearing the name of the caliph al-Mustali (Figure 7.9). ${ }^{46}$ The tapestry-woven compound bands of this textile's center and borders, formed of serial medallions within ornamental bands, compare well in form with those of Satan's painted robe.

For those who recognized the painted garment as a representation of tịnāz, its connotations would have been quite nuanced, for this was not an everyday garment. Although in actual practice țirāz textiles were not always produced under royal auspices, their inscriptions often referred to the monarch, provoking association with him. ${ }^{47}$ At the Fatimid court, where white was the imperial

colleagues Ana Cabrera and María Judith Feliciano for prompting me to examine this garment more closely and for their guidance as I did so.

The term "țirāz" originally referred to a variety of embroidered textiles, but it quickly came to refer to those inscribed with honorific text and sometimes referred by extension to the factories where such works were produced. I follow common practice here in applying it to the inscribed examples. See Louise W. Mackie, Symbols of Power: Luxury Textiles from Islamic Lands, 7 th-21st Centuries (Cleveland, OH: Cleveland Museum of Art, 2015), 85; see also Yedida K. Stillman, Paula Sanders, and Nasser Rabbat, "Țirāz," in Encyclopaedia of Islam. New Edition, 10 vols. ed. P. Bearman et al. (Leiden: Brill, 1986-2004), 10:534-538.

44 For examples and general background, see Mackie, Symbols of Power, 82-127, and Maurice Lombard, Les textiles dans le monde musulman: VII-XII siècles (Paris: Mouton, 1978), 219-221. For the uses of textiles at the court, see Paula Sanders, "Robes of Honor in Fatimid Egypt," in Robes and Honor: The Medieval World of Investiture, ed. Stewart Gordon (New York: Palgrave, 2001), 225-240.

45 Mackie, Symbols of Power, 85-86 and 96-98.

46 Béatrice Girault-Kurtzemann, "Le voile de sainte-Anne d'Apt," Bulletin du CIETA 75 (1998): 37-47; see also Mackie, Symbols of Power, 113-116.

Sanders, "Robes of Honor," 226-227. 


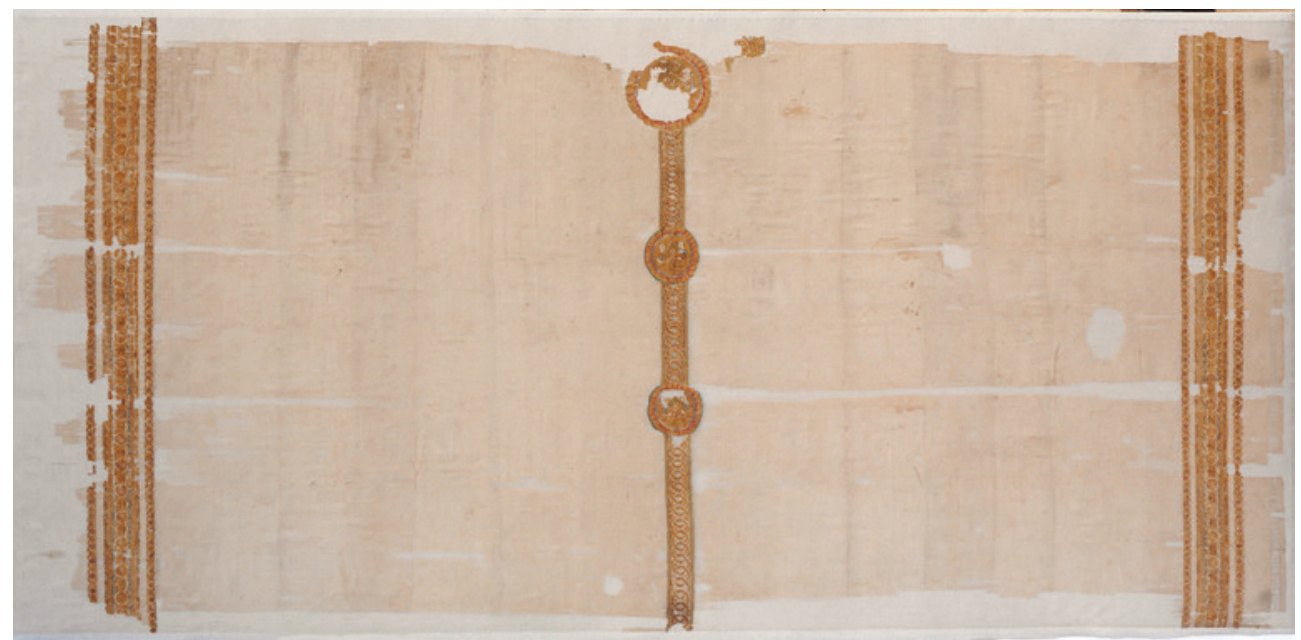

FIGURE 7.9 Tirāz dated 1097 and known as the "Veil of Ste.-Anne" (Apt, Cathedral of Ste.-Anne). PHOTO: GRAND ANGLE/PHILLIPPE GROMELLE

color, such textiles were both worn by the caliph and his elites and given as robes of honor to favored courtiers or visiting dignitaries. This practice was familiar in Iberia as well: the golden tunic and bornus (a hooded mantle) given to Ordoño IV by the Cordoban caliph al-Hakam II in 962, when the Asturian king visited his court, constitutes an early example. ${ }^{48}$ The circulation of tiirāz and other textiles through such gifts, as well as outright purchases, persisted for centuries among elite Iberians, who sometimes cut them into garments reflecting local fashion..$^{49}$ The narrowly-cut western style of Satan's robe at León, which differs notably from the loose tunic or untailored drape into which a țirāz textile would have been shaped for wear in Islamic lands, might have

48 Following Ibn-Hayyān, al-Maqqarī reports that the caliph bestowed on Ordoño "a tunic of gold tissue, and a bornús of the same material, with a belt of the purest gold, set with pearls and rubies of such magnitude and beauty that the eyes of the barbarian rested complacently on them. ..." See Ahmmad ibn Muhammad Maqqarī, Ibn al-Khațīb, and Pascual de Gayangos, The History of the Mohammedan Dynasties in Spain; Extracted from the Nafhu-ttíb min ghosni-l-Andalusi-r-rattíb wa táríkh Lisánu-d-Dín Ibni-l-Khattíb (London: Oriental Translation Fund of Great Britain and Ireland; W. H. Allen and Co., 1840), 2:165.

49 For surviving, if somewhat later, examples of this practice, see María Judith Feliciano, "Muslim Shrouds for Christian Kings? A Reassessment of Andalusi Textiles in ThirteenthCentury Castilian Life and Ritual," in Under the Influence: Questioning the Comparative in Medieval Castile, ed. Cynthia Robinson and Leyla Rouhi (Leiden: Brill, 2005), 101-132, at $112-113$. 
been understood as such a transformed, high-status garment. ${ }^{50}$ Its costly materials, especially the tapestry-woven band falling down its center in a manner reminiscent of a Byzantine imperial loros, would have suited it well for Satan's kingly disguise. ${ }^{51}$

Beyond its references to kingship, the luxurious qualities of this garment, with its diaphanous weave and gold-wrapped thread, also had potential to raise more complex associations by evoking the sensuality often attributed to Islamic culture by western Europeans. This suggestion deserves some caution, since stereotypes concerning Muslim luxury and sensuality developed most fully in the post-medieval west. ${ }^{52}$ However, lasciviousness was among the charges leveled by the ninth-century Cordobans who sought "martyrdom" through public attacks on Islam, and it threads through other texts of that century, including a surprising account of St. Pelagius's martyrdom that attributes the saint's execution not merely to his refusal to convert to Islam but to his rejection of the physical advances of the caliph Abd al-Rahman III. ${ }^{53}$ The theme became more muted in anti-Muslim polemics of the early twelfth century, which tended instead toward the dissection of Islamic doctrine and its potential to qualify as heresy. ${ }^{54}$ Nonetheless, combined with the devil's youthful appearance, which resonated with early monastic images of Ethiopian boys whose temptation of

$5^{\circ}$ On the ways in which such textiles were worn in Islamic lands, see Lisa Golombek, "The Draped Universe of Islam," in Content and Context of Visual Arts in the Islamic World, ed. Priscilla P. Soucek (New York: CAA and The Pennsylvania State University Press, 1988), 25-49, at 27-29.

$5^{1}$ The loros-like band is relatively rare in twelfth-century Iberian images, but when it appears, it usually worn by royal figures, whether good or evil. In the abovementioned Silos Beatus, for example, it is shared by Christ (fols. $18 \mathrm{v}$ and 21r), Nebuchadnezzar (fols. 228v, 232v), and the Whore of Babylon and the Kings of the Earth (fol. 182v). The practice was not limited to Iberia; see Janet Snyder, "Cloth from the Promised Land: Appropriated Tiraz Textile in Twelfth-Century French Sculpture," in Fabrications: Dress, Textiles, Clothwork, and Other Cultural Imaginings, ed. E. Jane Burns (New York: Palgrave McMillan, 2004), 145-164.

$5^{2}$ As classically articulated by Edward Said, Orientalism (New York: Pantheon, 1978).

53 On ninth-century anti-Muslim polemics as motivated partly by the appeal of Umayyad culture, see John Tolan, Saracens: Islam in the Medieval European Imagination (New York: Columbia University Press, 2002), 85-104. On the Pelayo tale, see Maribel Fierro, "Hostages and the Danger of Cultural Contact: Two Cases from Umayyad Cordoba," in Acteurs des transferts culturels en Méditerranée médiévale, ed. Rania Abdellatif et al. (Munich: Oldenbourg, 2012), 73-83, esp. 79-82, and Jeffrey A. Bowman, "Beauty and Passion in Tenth-Century Córdoba," in The Boswell Thesis: Essays on Christianity, Social Tolerance, and Homosexuality, ed. Matthew Kuefler (Chicago: University of Chicago Press, 2006), 236-253.

Tolan, Saracens, 147-155. 
the desert fathers was at times implicitly or overtly sexual, the opulent garment conceivably could have lent such a meaning. ${ }^{55}$

The probability that St. Martin's robe was understood as commenting on Islamic culture at some level is bolstered by a second hagiographical scene in the Panteón, located on a soffit to the south of St. Martin. Here, the equestrian St. George wages his own battle against the devil, striking downward with his spear into a struggling Satanic figure. Despite damage to the face, this devil preserves features of the conventionally monstrous type, with flame-like hair and horns still visible (Figure 7.10). However, he also carries a round shield of a type found frequently, although not exclusively, in Umayyad imagery. ${ }^{56} \mathrm{Al}-$ though this detail's association with Andalusi culture cannot be guaranteed, if such an association were intended here, it would have amplified that made by Satan's robe in the neighboring bay.

The fairly literal references to Andalusi culture made by these visual elements offer a richer context within which to understand the iconographic work done by the devil's Ethiopian likeness, and especially by the connotations of exoticism and distance it projected. Since the time of Pliny the Elder, the Ethiopian had been the paradigmatic foreigner, signifying a very wide range of Others which included many of the real and imagined outsiders of whom the early twelfth-century Leonese kingdom was becoming increasingly aware. For those in León, as for Europeans generally at this time, the boundaries of the known world had expanded rapidly as globally oriented phenomena such as pilgrimage, crusading, and eastern trade introduced western Europeans to the unfamiliar peoples who lived — or were imagined to livebeyond familiar borders. ${ }^{57}$ One result of this awareness was a proliferation of stereotypes aimed at setting these foreign peoples into graspable relation to the known European world, an effort intimately related to interest in the

55 On the sexual dimensions of these tales, see David Brakke, Demons and the Making of the Monk: Spiritual Combat in Early Christianity (Cambridge, MA: Harvard University Press, 2006), 166-181.

56 Martin (Queen as King, 147), identifies this shield as Muslim; similarly, Juan Zozaya has compared the shield held by a soldier in a fresco painted in San Baudelio de Berlanga (now Museo del Prado, Po7266) to Umayyad examples; see Juan Zozaya, "Algunas observaciones en torno a la ermita de San Baudelio de Casillas de Berlanga," Cuadernos de la Alhambra 12 (1976): 307-338, at 324. However, Milagros Guardia (San Baudelio, 374-376) cites manuscript examples employing the form in a Christian context and notes that round shields were also used by Christian soldiers throughout the twelfth century.

57 My use of the term "global" follows that of Janet Abu-Lughod, Before European Hegemony: The World System A.D. 1250-1350 (New York: Oxford University Press, 1989), esp. 3-20 and 32-40. See also Alicia Walker, "Globalism," Studies in Iconography 33 (2012): 183-196. 


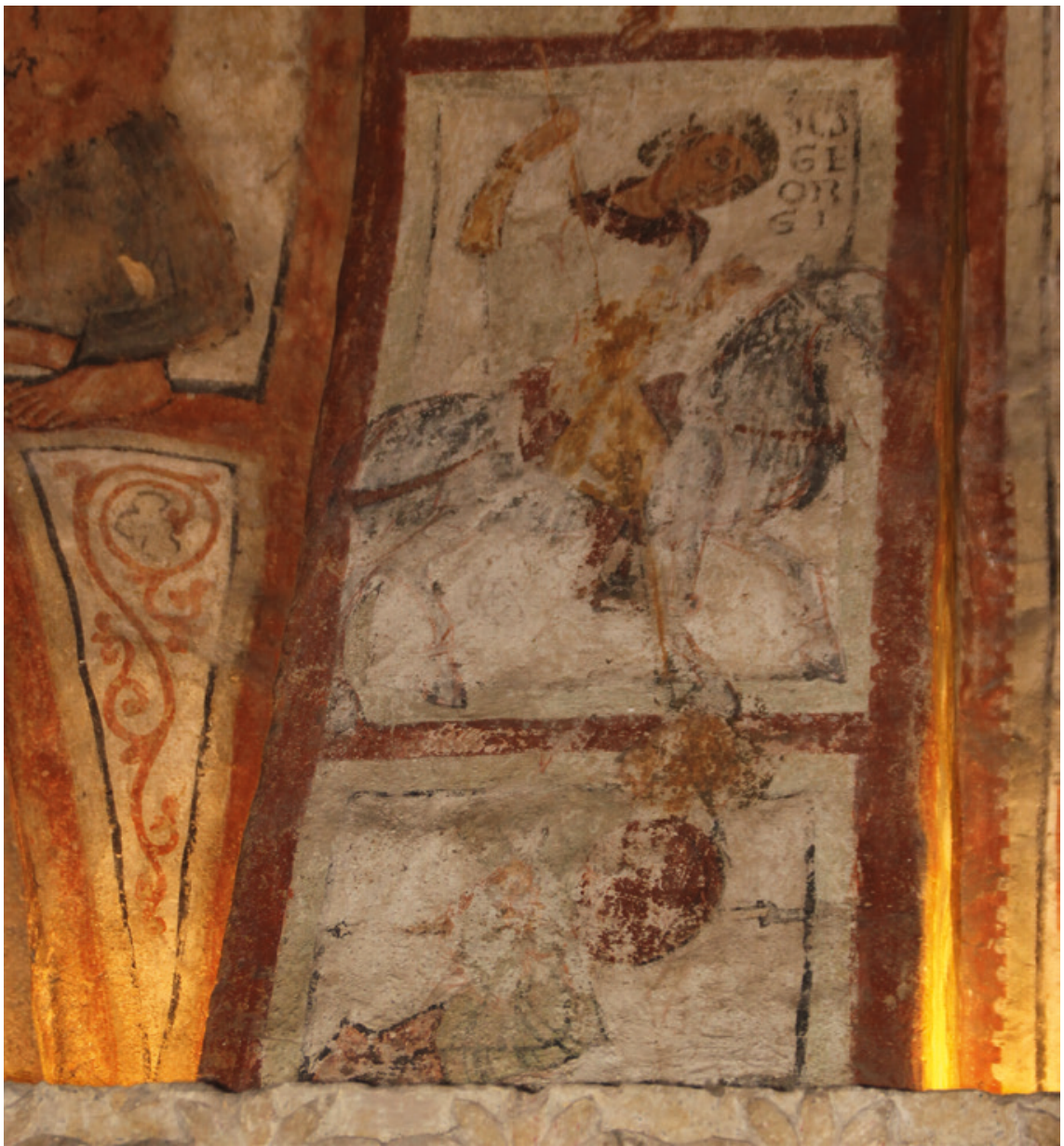

FIGURE 7.10 St. George battling the devil, Panteón de los Reyes, San Isidoro, León. PHOTO (C) MUSEO DE SAN ISIDORO DE LEÓN. ALL RIGHTS RESERVED; FULL AND PARTIAL REPRODUCTION PROHIBITED

so-called Monstrous Races, originally described by Classical authors as living beyond the known Mediterranean world, often in Ethiopia, where human populations shared space with fantastical figures such as headless Blemmyae and one-footed Sciopods. ${ }^{58}$

$5^{8}$ Friedman, Monstrous Races; Strickland, Saracens, Demons, and Jews, 29-59. For an admirably nuanced view of such encounters, see Shirin Khanmohamadi, In Light of Another's Word: European Ethnography in the Middle Ages (Philadelphia: University of Pennsylvania Press, 2014), esp. 11-36. 
The northern Iberian kingdoms are often omitted from discussions of this changing world view, perhaps because, in the eleventh and twelfth centuries particularly, they are assumed to have been preoccupied with their own internal confrontations. Yet much of the Classical information on which medieval knowledge of the world was based was readily available in Iberia through early medieval compilations, above all the Etymologies of the Visigothic scholar Isidore of Sevilla, who was, of course, the dedicatee of the church of San Isidoro in León. Isidore's work includes a discussion of the Monstrous Races that relies closely on Classical sources, especially Pliny's Natural History; it also provides the prototype for the world map found in numerous Beatus manuscripts to illustrate the apostles' evangelization routes. ${ }^{59}$ Several such maps locate the Races on a mysterious fourth continent located just beyond Ethiopia, illustrated particularly neatly in the Burgo de Osma Beatus, which depicts a gigantic Sciopod in its most characteristic pose, resting on its back with its single foot raised above its head, in this zone (Figure 7.11)..$^{60}$

The Sciopod's geographical proximity to Ethiopia in this image is explained by an inscription drawn from Isidore: "This region is unknown to us due to the heat of the sun and is uninhabitable. They say that the sciopods who have one foot and extraordinary speed live there, who, because of this aspect, are called sciopods by the Greeks because during the summer, lying down with their backs upon the ground, they shade themselves with the great size of their feet." ${ }^{61}$ Drawing on a conceptual elision as old as Pliny's text, which identified Sciopods and several other Monstrous Races as literally inhabiting Ethiopia, the conflation also reflects a tendency, common in both Classical and medieval writing, to combine or exchange the characteristics attributed to one peripheral group freely with another, as if allowing their shared distance from the familiar cultural center to dissolve the distinctions among them. ${ }^{62}$ If the

59 Isidore's treatment of the Monstrous Races appears in Etymologies 11.3.12-29; see The Etymologies of Isidore of Seville, ed. Stephen A. Barney et al. (New York: Cambridge University Press, 2006), 244-246. The Beatus map follows passages adopted from Isidore's De apostolis (VII, 9, 1-4) and De ortu et obitu partum; see Sandra Sáenz-López Pérez, The Beatus Maps: The Revelation of the World in the Middle Ages, trans. Peter Krakenberger and Gerry Coldham (Burgos: Siloé, 2014), 180-182.

6o Sáenz-López, Revelation of the World, 196-198 and 212-222; Williams, Visions of the End, 23.

61 Sáenz-López, Revelation of the World, 217-218.

62 Monique Mund-Dopchle, "Autour des sciopodes: la péripherie dans l'Antiquité," in Mythe et litterature: Études réunies et presentées, ed. Ernst Leonardy (Louvain la Neuve: Collége Erasme, 1994), 41-52, esp. 50-51. See also Serafín Moralejo Álvarez, "World and Time in the Map of the Osma Beatus," Apocalipsis Beati Liebanensis, 2:145-174. 


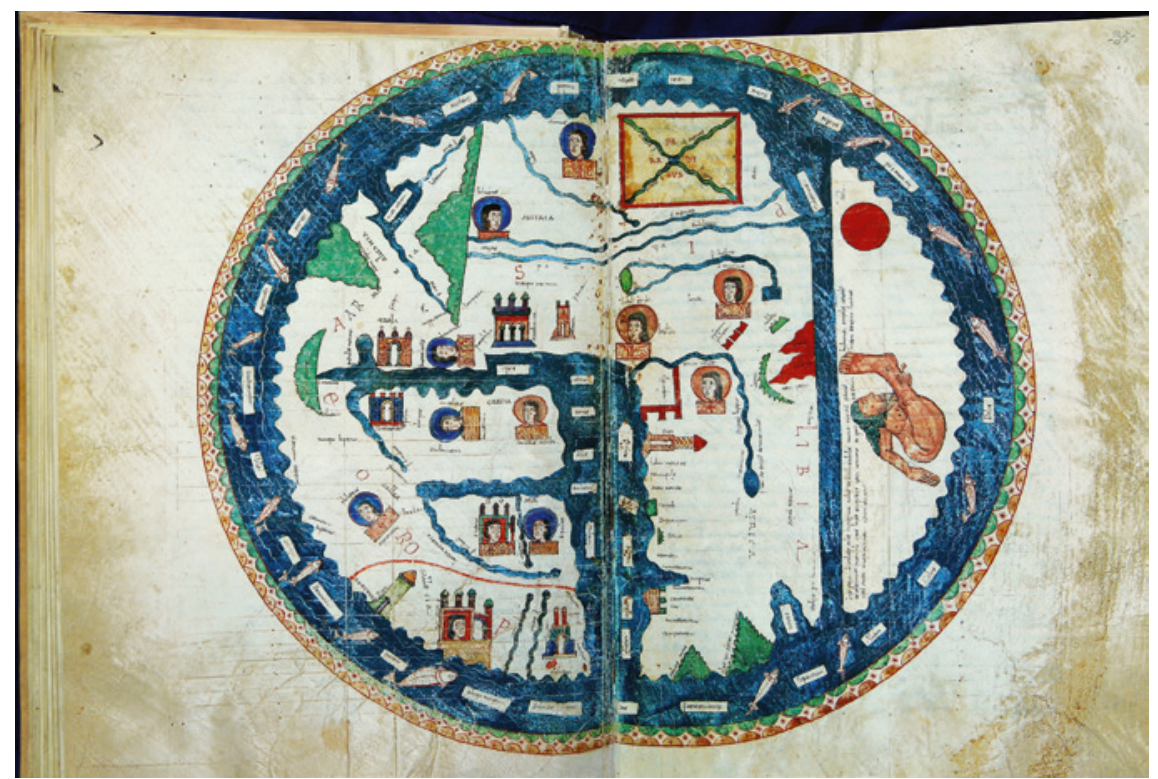

FIGURE 7.11 Mappamundi, Burgo de Osma Beatus (Burgo de Osma Cathedral, MS 1) fols. $34 \mathrm{v}-35 \mathrm{r}$.

PHOTO: HAMID SHAMS

Sciopod in the Osma map is presented, as Serafín Moralejo described it, "pars pro todo [sic], as the outermost limit of human diversity into which all the rest of humanity would fit," 63 it also entwines Ethiopia firmly within this cosmological view, rendering it just one more of the array of unfamiliar foreign cultures to be encountered by the apostles as they bore the Word to the edges of the earth. From this perspective, the dark-skinned Satan at San Isidoro extended its signification to include all manner of Others, opening a space as well for proximate foreigners like the Almoravids in the zones beyond Leonese lands.

I have proposed that the St. Martin scene at León, with its distinctive Satan figure, had potential to inspire an unusually wide range of associations in its viewers: with the beleaguered saints and deceptive devils of early Christianity, with the exemplary fortitude of the tempted Christ, and with the

63 Moralejo, "World and Time," 152. 
appealing yet dangerous difference of the Almoravid foe. But which of these resonated with the viewers who actually stood before the image in the early twelfth century? Although there is always some peril in speculation about the makeup of medieval viewing communities, doing so in this case is facilitated by the nature of the structure in which the painting appears, the so-called "Panteón de los Reyes." As its nickname reflects, this structure, built circa 1080 as the lower story of a royal palace, has long been understood and analyzed primarily as a mausoleum. ${ }^{64}$ This was certainly among its predominant functions after the middle of the twelfth century, but as Therese Martin in particular has pointed out, there is only limited material evidence that burial was its primary role when the paintings now under discussion were added. ${ }^{65}$ While this, of course, does not rule out the possibility of earlier funerary use, it should encourage the recognition that in the first decades of the twelfth century, the space also hosted a range of activities by the living. As a palatial lower story that facilitated royal passage into the church, it served as a gathering point and a transitional zone between royal and sacred spaces; like similar palace structures in Iberia and throughout much of Europe, it was suited to a number of functions, from the reception of visitors to court gatherings and ritual celebrations. ${ }^{66}$ Beyond the royal family itself, participants in these functions might have included courtiers, foreign visitors, and clergy, the last drawn from both San Isidoro and foundations throughout the kingdom. The viewers of the Panteón, then, were a select population whose literacy and cosmopolitanism well exceeded that of the more diverse public beyond its walls and likely predisposed them to appreciate complex or esoteric visual imagery.

64 Key scholarship on the structure's date includes John Williams, "San Isidoro in León, Evidence for a New History," Art Bulletin 55 (1973): 171-184, and Martin, Queen as King, 74-95. The persistence of scholarship analyzing it as a consistently funerary space is exemplified by Gerardo Boto Varela, "Arquitectura medieval. Configuración espacial y aptitudes funcionales," in Real Colegiata de San Isidoro. Relicario de la monarquía leonesa, ed. Constantino Robles García and Fernando Llamazares Rodríguez (León: Edilesa, 2007), 51-103, esp. 71.

65 Therese Martin, "Vie et mort dans le Panthéon de San Isidoro de León," Cahiers de SaintMichel de Cuxa 42 (2011): 153-164; see also Martin, Queen as King, 74-78. The fact that Alfonso VI established his own mausoleum at Sahagún rather than San Isidoro reinforces the tenuousness of a dynastic burial tradition there prior to Urraca's reign; on Sahagún, see José Luis Senra, "En torno a un espacio de evocación: las res gesta domini Adefonsi y la iglesia monástica de Sahagún," in La construcción medieval de la memoria regia, ed. Pascual Martínez Sopena and Ana Rodríguez (Valencia: Publicacions Universitat de València, 2011), 243-292.

Martin, "Vie et mort," 162-164; Martin, Queen as King, 132. 
The programmatic sophistication of this imagery, with its elaborate Christological cycle, theophanic vaults, diverse secondary figures, and extensive inscriptions, answered well to such an audience. Thematically diffuse and lacking the coherent focus on either funerary or palatial themes that might be expected in a painted program of this scale, it must have presented a complex read for even the most educated viewer. ${ }^{67}$ This complexity is reflected in its analyses by modern scholars, whom the paintings' thematic obscurity, and the lack of surviving comparanda, have left free to craft an unusually wide range of arguments about the space and its reception. ${ }^{68}$ A detailed review of this scholarship is not possible here, but recent interpretations can be clustered loosely into two groups, one leaning toward the paintings' commemorative and funerary significance and the other toward their relevance to temporal concerns. The former includes Antonio Viñayo González, who, unlike many other scholars, assumed the paintings to have been accessible to a wide and often unlettered public, for whom they would have formed a coherent catechetical Christological program structured in keeping with the recently abolished Hispanic liturgy; María Soledad de Silva y Verástegui, who interpreted both the paintings and the sculpture of the Panteón as fundamentally penitential; Manuel Castiñeiras González, who interpreted the two main Christological and Apocalyptic cycles as preparing the viewer to pass from a funerary space into the heavenly Jerusalem of the church; and Rose Walker and Miguel Cortés Arrese, who both emphasized the paintings' intercessory potential, citing redemptive themes in the paintings themselves and comparing the Panteón's architecture with cryptlike western structures found in other churches of the era. ${ }^{69}$

A considerably more temporal reading of the ensemble, by contrast, was made in the course of several publications by John Williams, who initially identified the presence of the French saint Martial in the Last Supper vault

67 An absence of obviously funerary themes is remarked upon, for example, by Peter K. Klein, "Entre paradis présent et Jugement dernier: Les programmes apocalyptiques et eschatologiques dans les porches du haut Moyen Age," in Avant-nefs et espaces d'accueil dans l'église entre le IVe et le XIIe siècle: Actes du colloque international du CNRS, Auxerre 17-20 Juin 1999, ed. Christian Sapin (Paris: Ed. du CTHS, 2002), 464-483.

68 The literature up to 1985 is concisely summarized by Sureda, Pintura románica en España, 65-68; some more recent arguments are highlighted below.

69 Antonio Viñayo González, San Isidoro in León: The Royal Pantheon; The Advent of Romanesque Architecture, Sculpture, Painting (León: Edilesa, 1995), 35-47; María Soledad de Silva y Verástegui, "Espacios para la penitencia pública y sus programas iconográficos en el románico hispano," Clio \& Crimen 7 (2010): 111-135, esp. 127-135; Manuel A. Castiñeiras González, "El programa enciclopédico de la Puerta del cielo en San Isidoro de León," Compostellanum 45/3-4 (2000): 657-694; Walker, "Panteón de los Reyes;" and Cortés, "Pinceladas bizantinas," 145-167. 
as a mark of the paintings' internationalism; he subsequently extended this view by arguing that the Panteón's decoration, in terms of both iconography and style, contributed to a concerted effort by Fernando I and his successors to commission cosmopolitan artistic programs that helped to communicate the authority of the Leonese capital. ${ }^{70}$ Therese Martin adopted a similarly temporal frame for her analysis of the paintings, interpreting multiple iconographic details, including elements of the hagiographical scenes, as specifically asserting the legitimacy of the recently crowned Queen Urraca to the Panteón's elite viewership. ${ }^{71}$

Emphasized by the latter two authors but shared at some level by almost all others is the conviction that the viewership of the Panteón was a selective one, limited primarily to an elite circle of courtiers and visitors with significant relationships to the ruling family. They also concur in assuming that the paintings were designed to speak in some way to this viewership, often in the service of the royal family's authoritative agenda, a conclusion supported by the paintings' decisive blending of ruler portraits, calendrical imagery, and favored local saints into a complex Christological program that in its own right supports the case for universal, God-given rule. To these claims, I would add a third: that the sophistication of the viewers whom this program addressed would have prepared them to recognize most, if not always all, of the various signs of difference and danger confronted by St. Martin, whether the tempting Ethiopian youth of monastic legend, the supernatural Adversary of the Gospels and Apocalypse, the desirably deceptive Fatimid țirāz, or the foreign face and form of a being from beyond León's own borders. Their worldly self-awareness must have played a role as well in the community's ongoing donation of expensive treasury objects, the international origins and complex cultural valences of which are so richly highlighted by other authors in the present volume. Taken together, both objects and imagery well affirm John Williams's claim that "the true context for these paintings ... was the cultural revolution initiated by Fernando's contacts with centers north of the Pyrenees and advanced by his son, Alfonso vi" —and, one might justifiably add, by his granddaughter Urraca. ${ }^{72}$

With its curious concoction of multiple iconographic strands, the Temptation of St. Martin at León both argues for and speaks to the concerns of its

70 Williams, "Marcialis Pincerna," 29-36; Williams, "León: Iconography of a Capital," $252-256$.

71 Martin, Queen as King, 132-152.

72 John Williams, "Review of Constantino Robles García and Fernando Llamazares Rodríguez, Real Colegiata de San Isidoro: Relicario de la monarquía leonesa," Speculum 84/ 2 (Apr., 2009): 488-49o, at 489 . 
palatine viewership. As such, it manifests a tension between tradition and innovation, and between foreign and familiar, that speaks eloquently of its community's understanding of the world surrounding the complex at San Isidoro. In its multilayered invocation of both an ancient, supernatural enemy and the actual and imaginary foes that loomed beyond León, it offers a tempting glimpse into the rich strata of images, objects, texts, and ideas that contributed to the emergence of both treasury and church as lasting material witnesses to Leonese royal and cultural ambition.

\section{Acknowledgments}

Republication of this study in the present volume was supported by the Index of Medieval Art (Princeton University) and The Medieval Iberian Treasury in Context: Collections, Connections, and Representations on the Peninsula and Beyond (National Research Challenge Grant, Spanish Ministry of Science, Innovation, and Universities, AEI/FEDER, RTI2018-o98615-B-Ioo, 2019-2O22, PI Therese Martin). 